\title{
ANALYTIC NETWORK PROCESS FOR DECIDING DISASTER RECOVERY PROGRAM IN YOGYAKARTA INDONESIA
}

\author{
Ignatius Luddy Indra Purnama \\ Department of Industrial Engineering \\ Universitas Atma Jaya, Yogyakarta, Indonesia \\ E-mail: luddy_indra@staff.uajy.ac.id \\ Ririn Diar Astanti \\ Department of Industrial Engineering \\ Universitas Atma Jaya, Yogyakarta, Indonesia \\ E-mail: ririn@mail.uajy.ac.id \\ Hery \\ Department of Industry, Trade, and Cooperatives Sleman Regency, Indonesia \\ Mujgan Sagir Ozdemir \\ Eskisehir Osmangazi University, Eskisehir, Turkey \\ E-mail: mujgan.sagir@gmail.com
}

\begin{abstract}
Mount Merapi volcano eruption in Yogyakarta Indonesia on November 2010 resulted many survivors who most of them worked as a farmer that lived surround the mountain lost their jobs. In addition, as the volcano destroyed their home they had to live in the temporary shelter provided by the government. They lived in the temporarily shelter until their house was rebuilt. Disaster recovery program was conducted by the government to help the survivors. One of the purposes of that program is to empower the survivors, especially the women by giving them skills. Those skills is hoped to enable them doing small scale economies activities in order to generate additional income. However, the local government faced the problem in determining appropriate skills for the survivors. Data in the past showed us that not all skills were appropriate to them and supported them in generating small scale economies activities. The model based on Analytic Network Process is developed in this paper for disaster recovery program by deciding the type of the skills that have to be trained to the survivors, especially the woman.
\end{abstract}

Keywords: Disaster Recovery Program, Analytic Network Process, Woman Empowerment

\section{Introduction}

According to Indonesian National Board for Disaster Management (BNPB), Mount Merapi volcano eruption in Yogyakarta Indonesia on November 2010 affected the community including economical, education and health aspects. Mount Merapi is located in Sleman Regency, in the northern part of province of Yogyakarta Special Region. The total loss resulted from this eruption reached 4.23 trillion rupiahs, where losses from agricultural sector reached 1.326 trillion rupiahs or $43 \%$ from the total loss and losses from industrial sector especially Small Medium Enterprises reaches 382 billion rupiahs or $13 \%$ from the total loss (BNPB, 2011) The eruption resulted many survivors who most of them worked as a farmer that lived surround the mountain lost their jobs. In addition, as the volcano destroyed their home they had to live in the temporary shelter provided by the government. They lived 
in the temporarily shelter until their house was rebuilt. As they lost their jobs, the survivors have to think how to find other jobs to generate the income.

During these three years after the eruption, many disaster recovery programs have been conducted by the government and non-government organization to recover the survivors. For example the recovery program conducted by Department of Industry, Trade, and Cooperatives Sleman Regency (Disperindagkop Sleman). Disaster recovery program was conducted by the government to help the survivors. One of the purposes of that program is to empower the survivors, especially the women by giving them skills. Those skills is hoped to enable them doing small scale economies activities in order to generate additional income. These programs were conducted in many villages affected by the volcano eruption. Two villages were observed in this research. They are Kliwang Village and Gondang Village. The results from our interview to the survivors conducted in March 18, 2013 showed us that not all skills given to them were appropriate to them and were able to support them in generating small scale economies activities. In addition, according to our interview to Disperindagkop Sleman Regency on March 5, 2013 showed us that Disperindagkop have not conducted any evaluation yet regarding the decision to determine the recovery program that have to be given to the survivors. Therefore, the research in this paper is trying to develop a model based on Analytic Network Process (ANP) in order for the Disperindagkop Sleman Regency to make a decision the type of skills that have to be given to the survivor during post disaster recovery program, especially for the woman.

\section{Literature Review}

Research on disaster management (pre-, during, and post disaster) had been done by many researchers in the past. Thurairajah and Baldry (2010) conducted the research related to post disaster recovery program especially by investigating the factors that affect woman empowerment in Sri Lanka and stated that "one of the important factors that can play a major role within the post disaster reconstruction in Sri Lanka". Kusumasari and Alam (2012a) conducted the research on examining the capability of government in disaster management including pre-, during, and post disaster in Indonesia. Cox et al. (2011) studied post disaster recovery process by examining salience of place, identity, and social capital for two rural communities who were affected by wildfire in British Columbia. Kusumasari and Alam (2012b) in other research proposed a local wisdom-based disaster recovery model in Bantul district, Yogyakarta, Indonesia. Chang et al (2012) did the research by comparing two resourcing approaches (donor driven and contractor driven) in Indonesia and China by investigating the factors that affected post-disaster resource availability. Hoeberichts (2012) conducted the research related post disaster recovery program by focusing on treating the trauma of the survivors using the method called Council. To the best of author's knowledge there were no researches had been found related to determining post disaster recovery program using Analytic Network Process (ANP).

\section{Objective}

The research in this paper tries to develop a model based on Analytic Network Process in order to help for the Department of Industry, Trade, and Cooperatives (Disperindagkop) Sleman Regency to make a decision the type of skills that have to be given to the survivor during post disaster recovery program, especially for the woman. This decision is crucial as if the skill given to the survivor is appropriate then it is hoped that it can enable the survivor to generate small scale of economic activities. Therefore they might have an additional income to support the family.

\section{Research Methodology}

As it was mentioned in Section 1, Disperindagkop Sleman Regency have not conducted any evaluation yet regarding the decision to determine the recovery program that have to be given to the survivors, so that the recovery program that is given to the survivor can support them in generating income. This is a critical part because if the recovery program does not fit with the need and the capability of the survivors, the recovery program is meaningless. Based on our interview with 
Disperindagkop Sleman Regency and the survivors (12 respondents), criteria are defined and are grouped in clusters. They are human resource (motivator, production skill, educational level, leader, marketing skill, experience, entrepreneurship, creativity), stakeholder (university, government, non government organization), characteristic of the product (uniqueness, complexity of the production process, cost of goods sold), market (market opportunity, market trend), and raw material (price of raw material, access to get raw material, availability of material). Detail results of our interview to the survivors (12 respondents) can be seen in Table 1.

Once the model was developed, then we asked the respondents to give their opinion on pairwise comparison steps. The respondents for our research were the survivors from Kliwang and Gondang Village (16 respondents $-1^{\text {st }}$ and $2^{\text {nd }}$ group) and from Disperindagkop Sleman Regency ( 1 respondent $-3^{\text {rd }}$ group). The disaster recovery program that was given to the $1^{\text {st }}$ group is handycraft skill while for the second group is food making and processing skill. The $1^{\text {st }}$ group and $2^{\text {nd }}$ consists of 9 and 7 respondents respectively. At first each group did pairwise comparison among themselves on August 26,2013 . The result from this activity shows us that the value put in pairwise comparison is extremely different between the first two groups (survivors) and the third group (Disperindagkop Sleman Regency). At this point it can be concluded that there are gaps between the need of the community and what the government and non government organization have given to the community related to recovery program after eruption.

After reporting this result to Disperindagkop Sleman Regency, they wanted us to develop two models. The first model uses the pairwise comparison values from the survivors and the second one uses the pairwise comparison values from Disperindagkop Sleman Regency.

\section{Model Analysis}

The research in this paper is modeled using ANP approach and is solved using Super Decisions software with the following steps.

Step 1. Formulating Decision Network

According to the criteria and sub criteria that are explained in the previous section, the ANP model including the interrelation among criteria and sub criteria can be seen in Figure 1.

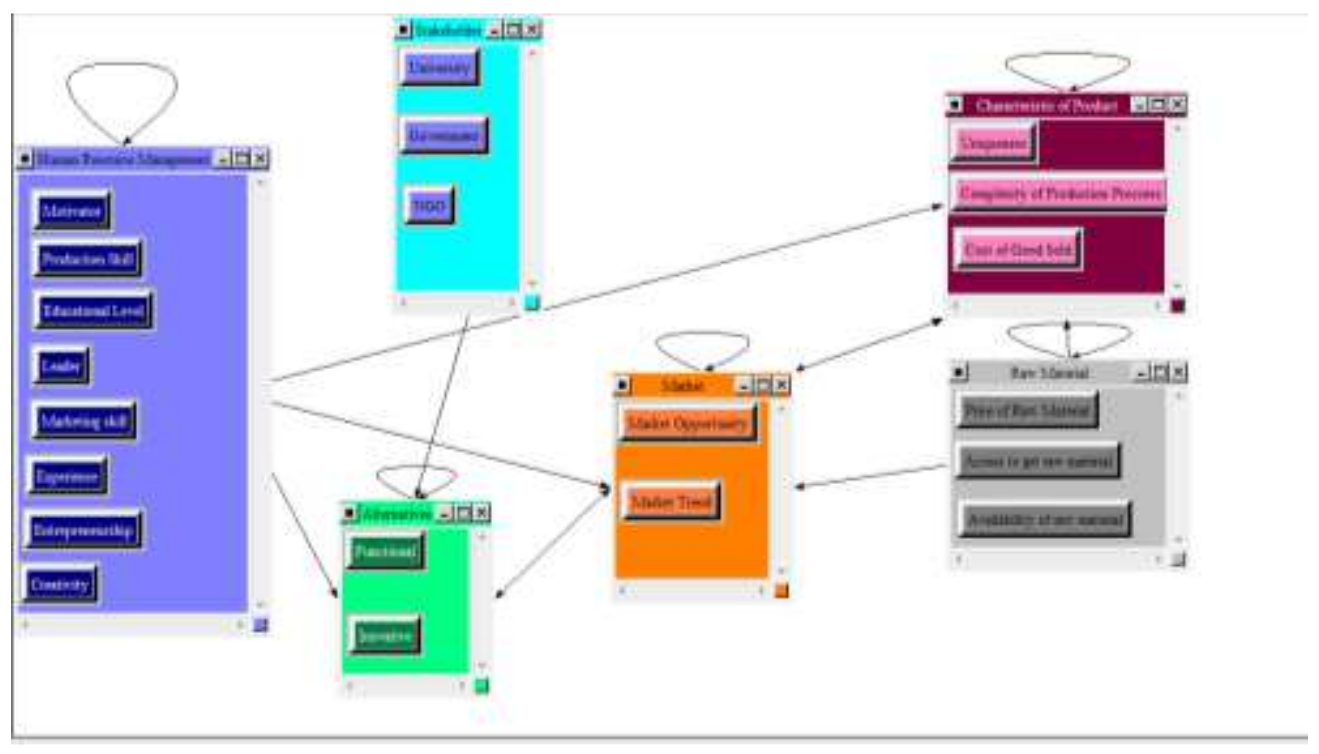

Figure 1.ANP Mode 
Table 1. Result of Interview to the Survivors

\begin{tabular}{|c|c|c|c|c|c|c|c|c|c|c|c|c|c|}
\hline \multicolumn{2}{|c|}{$\begin{array}{l}\text { Occupation before } \\
\text { eruption }\end{array}$} & \multicolumn{2}{|c|}{$\begin{array}{l}\text { Recovery program after } \\
\quad \text { eruption }\end{array}$} & \multicolumn{2}{|c|}{$\begin{array}{l}\text { Occupation after } \\
\text { eruption }\end{array}$} & \multirow{2}{*}{$\begin{array}{l}\text { Effect on recovery } \\
\text { program in } \\
\text { generating incomes }\end{array}$} & \multirow{2}{*}{$\begin{array}{l}\text { Proposed recovery } \\
\text { program }\end{array}$} & \multicolumn{6}{|c|}{$\begin{array}{l}\text { Factors that affects the successfulness of the recovery program in term of generating } \\
\text { income }\end{array}$} \\
\hline Husband & Wife & Husband & Wife & Husband & Wife & & & 1 & 2 & 3 & 4 & 5 & 6 \\
\hline 1 & 4 & A & B & 1 & 4 & B & $\mathrm{D}$ & $\mathrm{X}$ & $\mathrm{X}$ & $\mathrm{X}$ & & $\mathrm{X}$ & \\
\hline 2 & 4 & $\mathrm{G}$ & $\mathrm{B}, \mathrm{C}, \mathrm{D}$ & 3 & 4 & $\mathrm{~B}, \mathrm{C}$ & $\mathrm{E}$ & $\mathrm{X}$ & $\mathrm{X}$ & $\mathrm{X}$ & $\mathrm{X}$ & $\mathrm{X}$ & \\
\hline 2 & 4 & $\mathrm{G}$ & $\mathrm{B}, \mathrm{C}, \mathrm{D}$ & 3 & 4 & $\mathrm{~B}, \mathrm{C}, \mathrm{D}$ & $\mathrm{E}$ & & & $\mathrm{X}$ & & & \\
\hline 2 & 4 & $\mathrm{G}$ & $\mathrm{B}, \mathrm{C}$ & 2 & 4 & $\mathrm{C}$ & $\mathrm{G}$ & $\mathrm{X}$ & $\mathrm{X}$ & $X$ & $\mathrm{X}$ & $X$ & $X$ \\
\hline 5 & 4,6 & A & $\mathrm{B}, \mathrm{C}$ & 5 & 4,6 & $\mathrm{C}$ & $\mathrm{D}, \mathrm{G}$ & $X$ & $\mathrm{X}$ & $\mathrm{X}$ & $\mathrm{X}$ & $X$ & \\
\hline 2 & 4 & $\mathrm{G}$ & $\mathrm{B}, \mathrm{C}$ & 7 & 8 & $\mathrm{C}$ & $\mathrm{H}$ & $X$ & & & & & \\
\hline 2 & 2 & $\mathrm{G}$ & $\mathrm{C}, \mathrm{E}$ & 2 & 2 & $E$ & $\mathrm{E}$ & & & & $\mathrm{X}$ & & \\
\hline 2 & 4 & $\bar{G}$ & $\mathrm{C}, \mathrm{E}$ & 3 & 4 & $\mathrm{~B}, \mathrm{C}$ & $\mathrm{E}$ & & & $\mathrm{X}$ & & & \\
\hline 3 & 1 & $\mathrm{~A}$ & $\mathrm{~B}, \mathrm{C}, \mathrm{D}$ & 1 & 1 & $\mathrm{D}$ & $\mathrm{D}, \mathrm{E}$ & & & & & $X$ & \\
\hline 2 & 4 & A & $\mathrm{B}, \mathrm{C}$ & 3 & 4 & C & $\mathrm{E}$ & $\mathrm{X}$ & $\mathrm{X}$ & $X$ & $\mathrm{X}$ & $X$ & $\mathrm{X}$ \\
\hline 9 & 4 & $\mathrm{~A}$ & $\mathrm{~B}, \mathrm{C}, \mathrm{D}$ & 9 & 4 & C,D & $\mathrm{E}$ & $X$ & & $\mathrm{X}$ & $\mathrm{X}$ & $\mathrm{X}$ & \\
\hline 3 & 4 & $\mathrm{~J}$ & $\mathrm{~B}, \mathrm{C}, \mathrm{D}, \mathrm{E}$ & 3,10 & 4 & $\mathrm{C}, \mathrm{I}$ & $\mathrm{E}$ & $X$ & $\mathrm{X}$ & $\mathrm{X}$ & $\mathrm{X}$ & $X$ & \\
\hline 2 & 4 & $\mathrm{G}$ & $\mathrm{B}, \mathrm{C}$ & 11 & 4 & $\mathrm{C}$ & $\mathrm{E}$ & $X$ & $X$ & & $\mathrm{X}$ & $\mathrm{X}$ & \\
\hline 11 & 4 & $\mathrm{G}$ & $\mathrm{E}, \mathrm{I}$ & 11 & 4 & $\mathrm{E}$ & $\mathrm{E}$ & $X$ & $X$ & $\mathrm{X}$ & $\mathrm{X}$ & $X$ & \\
\hline 2 & 4 & $\mathrm{G}$ & $\mathrm{B}, \mathrm{C}$ & 10 & 4 & $\mathrm{C}$ & $\mathrm{D}$ & $X$ & & $\mathrm{X}$ & & $X$ & \\
\hline 11 & 4 & $\mathrm{~A}$ & $\mathrm{~B}, \mathrm{C}, \mathrm{I}$ & 11 & 4 & I & $\mathrm{E}$ & $X$ & $X$ & $X$ & $\mathrm{X}$ & $X$ & \\
\hline 12 & 1 & A & $\mathrm{B}, \mathrm{C}$ & 1 & 1 & $\mathrm{C}$ & $\mathrm{D}$ & $\mathrm{X}$ & & $\mathrm{X}$ & & $\mathrm{X}$ & \\
\hline
\end{tabular}


Note:

\begin{tabular}{|l|l|r|l|l|l|l|l|l|}
\hline \multicolumn{2}{|c|}{ Occupation } & \multicolumn{3}{c|}{ Recovery Program } & \multicolumn{2}{c|}{$\begin{array}{l}\text { Factorsaffect succesfullness } \\
\text { of the program }\end{array}$} \\
\hline 0 & Jobless & 8 & Embroiderers & A & None & & $\begin{array}{l}\text { Availability of raw } \\
\text { material }\end{array}$ \\
\hline 1 & Businessman/woman & 9 & Employee & B & Batik & 2 & Price of raw material \\
\hline 2 & Farmer & 10 & Stock farmer & C & Embroidery & 3 & $\begin{array}{l}\text { Level of difficulties of } \\
\text { the product }\end{array}$ \\
\hline 3 & Sand miner & 11 & Worker & D & Bakery & 4 & Good coordination \\
\hline 4 & Housewife & & & E & Sewing & 5 & $\begin{array}{l}\text { Marketability of the } \\
\text { product }\end{array}$ \\
\hline 5 & Teacher & & & F & Carpenting & 6 & Product trend \\
\hline 6 & Trader & & & G & Marketing & & \\
\hline 7 & Carpenter & & & H & $\begin{array}{l}\text { Handicraft and } \\
\text { Accecories }\end{array}$ & & \\
\hline & & & & I & Stock farming & & \\
\hline
\end{tabular}

Step 2. Formulation of Supermatrix

Based on structure of the problem presented in Figure 1, then the structure of supermatrix can be formulated as it is shown in Figure 2.

$$
W=\left[\begin{array}{cccccc}
w_{11} & 0 & 0 & w_{14} & w_{15} & w_{16} \\
0 & w_{22} & 0 & 0 & 0 & 0 \\
0 & w_{32} & w_{33} & w_{34} & 0 & w_{36} \\
w_{41} & w_{42} & w_{43} & w_{44} & 0 & w_{47} \\
0 & 0 & 0 & 0 & 0 & 0 \\
0 & 0 & w_{63} & 0 & 0 & w_{66}
\end{array}\right]
$$

Figure 2. Supermatrix 
Step 3. Obtaining Cluster Weight Matrix

Cluster Weight Matrix is obtained by doing cluster comparisons then its value is normalized and synthesized to get relative priority of each cluster. The question was asked to decision maker is for example "how much more the "Market" has influence on Alternatives comparing to the Human Resource Management ". In the research of this paper, the pairwise comparisons were done by two groups of respondents. The first group is the survivors themselves, and the second group is the experts from Disperindagkop Sleman Regency. Therefore we got two cluster weight matrices as shown in Table 2 and Table 3 respectively. It is noted that as there are 12 respondents belong to this survivors group then focus group discussion is conducted in order to get opinion from them. If during focus group discussion, no single value is reached then geometric mean is used.

Table 2. Cluster Weight Matrix from the first group (survivors)

\begin{tabular}{|l|c|c|c|c|c|c|}
\hline \multicolumn{1}{|c|}{$\begin{array}{c}\text { Cluster } \\
\text { Node } \\
\text { Label }\end{array}$} & Alternatives & $\begin{array}{c}\text { Characteristic } \\
\text { of Product }\end{array}$ & $\begin{array}{c}\text { Human } \\
\text { Resource } \\
\text { Management }\end{array}$ & Market & Raw Material & Stakeholder \\
\hline Alternatives & 0.3333 & 0.0000 & 0.1192 & 0.1703 & 0.0000 & 1.0000 \\
\hline $\begin{array}{l}\text { Characteristic } \\
\text { of Product }\end{array}$ & 0.0000 & 0.1722 & 0.1406 & 0.6516 & 0.7096 & 0.0000 \\
\hline $\begin{array}{l}\text { Human } \\
\text { Resource } \\
\text { Management }\end{array}$ & 0.0000 & 0.0489 & 0.1051 & 0.0000 & 0.0000 & 0.0000 \\
\hline Market & 0.6667 & 0.7789 & 0.6350 & 0.1781 & 0.1550 & 0.0000 \\
\hline Raw Material & 0.0000 & 0.0000 & 0.0000 & 0.0000 & 0.1354 & 0.0000 \\
\hline Stakeholder & 0.0000 & 0.0000 & 0.0000 & 0.0000 & 0.0000 & 0.0000 \\
\hline
\end{tabular}

Table 3. Cluster Weight Matrix from the second group (Disperindagkop Sleman Regency)

\begin{tabular}{|l|c|c|c|c|c|c|}
\hline \multicolumn{1}{|c|}{$\begin{array}{c}\text { Cluster } \\
\text { Node } \\
\text { Label }\end{array}$} & Alternatives & $\begin{array}{c}\text { Characteristic } \\
\text { of Product }\end{array}$ & $\begin{array}{c}\text { Human } \\
\text { Resource } \\
\text { Management }\end{array}$ & Market & Raw Material & Stakeholder \\
\hline Alternatives & 0.3333 & 0.0000 & 0.1086 & 0.1703 & 0.0000 & 1.0000 \\
\hline $\begin{array}{l}\text { Characteristic } \\
\text { of Product }\end{array}$ & 0.0000 & 0.1840 & 0.0812 & 0.1781 & 0.2185 & 0.0000 \\
\hline $\begin{array}{l}\text { Human } \\
\text { Resource } \\
\text { Management }\end{array}$ & 0.0000 & 0.7531 & 0.2098 & 0.0000 & 0.0000 & 0.0000 \\
\hline Market & 0.6667 & 0.0629 & 0.6004 & 0.6516 & 0.7147 & 0.0000 \\
\hline Raw Material & 0.0000 & 0.0000 & 0.0000 & 0.0000 & 0.0668 & 0.0000 \\
\hline Stakeholder & 0.0000 & 0.0000 & 0.0000 & 0.0000 & 0.0000 & 0.0000 \\
\hline
\end{tabular}

Step 4 Obtaining Unweighted Matrix

Unweighted matrix is obtained by put the relative priority based on the pairwise comparison between elements that have dependencies on each other. The result of pairwise comparison for the survivor group is given in Table 4 while for the Disperindagkop Sleman Regency is presented in Table 5. 
Table 4. The Result of Pairwise Comparison of the Survivors Group

\begin{tabular}{|c|c|c|c|}
\hline \multicolumn{4}{|c|}{ Cluster comparison with respect to Characteristics of Product } \\
\hline Characteristics of Product & $\sqrt{6 \times 8} \approx 7$ & & Market \\
\hline Characteristics of Product & & $\sqrt{9 x 9} \approx 9$ & Human Resource \\
\hline Market & & $\sqrt{7 x 7} \approx 7$ & Human Resource \\
\hline \multicolumn{4}{|c|}{ Cluster comparison with respect to Raw Material } \\
\hline Raw material & $\sqrt{7 x 9} \approx 8$ & & $\begin{array}{l}\text { Characteristics of } \\
\text { Product }\end{array}$ \\
\hline Raw material & $\sqrt{2 x 4} \approx 3$ & & Market \\
\hline Characteristics of Product & $\sqrt{2 \times 4} \approx 73$ & & Market \\
\hline \multicolumn{4}{|c|}{ Cluster comparison with respect to Market } \\
\hline Characteristics of Product & & $\sqrt{2 x 2} \approx 2$ & Market \\
\hline Characteristics of Product & & $\sqrt{2 \times 2} \approx 2$ & $\begin{array}{l}\text { Human Resource } \\
\text { Management }\end{array}$ \\
\hline Market & $\sqrt{6 \times 8} \approx 7$ & & Sumber daya manusia \\
\hline \multicolumn{4}{|c|}{ Cluster comparison with respect to Human Resource } \\
\hline Alternative & & $\sqrt{2 x 2} \approx 2$ & $\begin{array}{l}\text { Characteristics of } \\
\text { Product }\end{array}$ \\
\hline Alternative & & $\sqrt{2 x 2} \approx 2$ & Market \\
\hline Alternative & & $\sqrt{7 x 9} \approx 8$ & Human Resource \\
\hline Characteristics of Product & $\sqrt{2 \times 2} \approx 2$ & & Market \\
\hline Characteristics of Product & & $\sqrt{9 \times 9} \approx 9$ & Human Resource \\
\hline Market & & $\sqrt{7 x 9} \approx 8$ & Human Resource \\
\hline \multicolumn{4}{|c|}{ Cluster comparison with respect to Alternative } \\
\hline Alternative & & $\sqrt{2 \times 2} \approx 2$ & Pasar \\
\hline \multicolumn{4}{|c|}{ Node comparison with respect to Government } \\
\hline Functional & & $\sqrt{6 x 8} \approx 7$ & Inovative \\
\hline \multicolumn{4}{|c|}{ Node comparison with respect to University } \\
\hline Functional & $\sqrt{4 x 6} \cong 5$ & & Inovative \\
\hline \multicolumn{4}{|c|}{ Node comparison with respect to NGO } \\
\hline Functional & $\sqrt{2 x 4} \approx 3$ & & Inovative \\
\hline \multicolumn{4}{|c|}{ Node comparison with respect to Uniqueness } \\
\hline Market opportunity & $\sqrt{2 x 2} \approx 2$ & & Market trend \\
\hline \multicolumn{4}{|c|}{ Node comparison with respect to Market Trend } \\
\hline Functional & $\sqrt{2 x 2} \approx 2$ & & Inovative \\
\hline \multicolumn{4}{|c|}{ Node comparison with respect to Motivator } \\
\hline Entrepreneur & $\sqrt{7 x 9} \approx 8$ & & Production skill \\
\hline \multicolumn{4}{|c|}{ Node comparison with respect to Creativity } \\
\hline Functional & $\sqrt{5 \times 7} \approx 6$ & & Inovative \\
\hline
\end{tabular}

Step 5. Obtaining Weight Matrix and Limit Matrix

In this step the unweighted matrix is multiplied by cluster weight matrix and normalized for each column to get weighted matrix. Then, Limit Matrix is obtained by raising the matrix to powers until the value in the weight matrix has converged. 
Table 5. The Result of Pairwise Comparison of Disperindagkop Sleman Regency

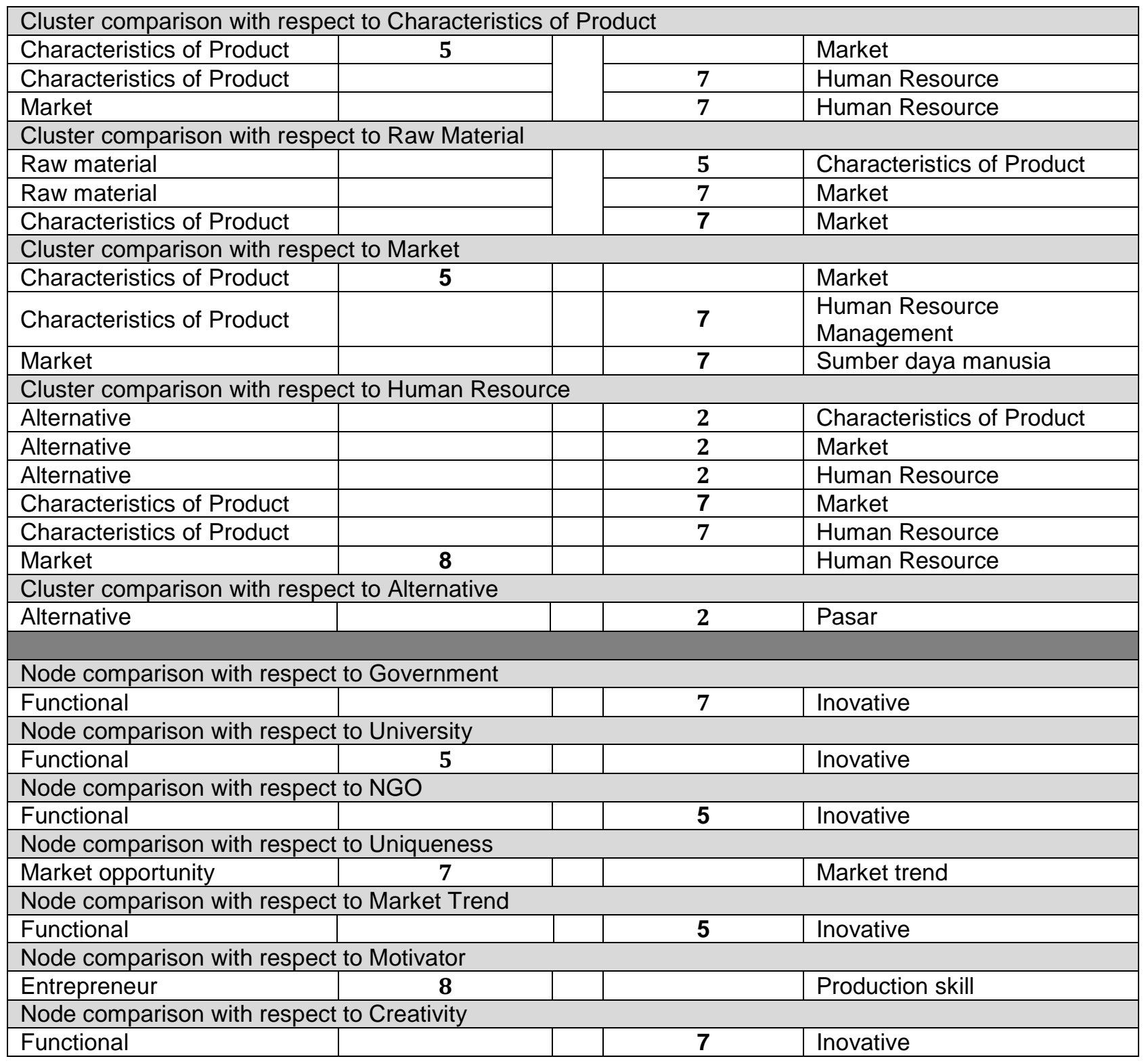


Step 6. Synthesis

This step is done in order to get final priority based on pairwise comparison from government point of view (Disperindagkop Sleman regency) and the final priority based on pairwise comparison from the survivors point of view.

There are 3 steps in the Synthesis part which are:

Step a. Take all values from Limit Matrix in the cluster Alternative. This value represents the priority of each alternative. There are two alternatives in there cluster matrix. They are the alternative represents the skill to make Functional Product and other alternative represent the skill to make Inovative Product. These values are then put in the Raw column. as it is shown in Table 6 and Table 7. Raw column is a column matrix with its size is $m x l$, where $m$ is the number of alternatives.

Table 6. Synthesis based on the input from survivors

\begin{tabular}{|c|c|c|c|}
\hline Alternatives & Ideals & Normalized & Raw \\
\hline Functional & 1.00 & 0.67 & 0.06 \\
\hline Innovative & 0.33 & 0.33 & 0.03 \\
\hline$\sum$ & & 1.00 & 0.09 \\
\hline
\end{tabular}

Table 7. Synthesis based on the input from Disperindagkop Sleman Regency

\begin{tabular}{|c|c|c|c|}
\hline Alternatives & Ideals & Normalized & Raw \\
\hline Functional & 1.00 & 0.32 & 0.07 \\
\hline Innovative & 0.68 & 0.68 & 0.15 \\
\hline$\sum$ & 1.00 & 0.32 & 0.07 \\
\hline
\end{tabular}

Step b. Normalization

In this step all of values in the Raw column are summed up, then each value in each row is divided by the sum of the Raw column.

Step c. Idealization

In this step, each normalized value is divided by the biggest normalized value.

\section{Conclusion}

Based on the result from our analysis it is concluded that from survivors point of view, the skill that enables them to produce functional product is more preferable for them. After getting the result, we conducted the interview to gain any feedback from them. The survivors said that the skill to make functional product such as food and beverages is more preferable, because the functional product is easy to be marketed. In addition, food and beverage is the primary need of every human being, so if they sell this type of product, they will get daily income. Eventhough they have realized already that the margin profit for this functional product is lower than that of innovative product. In addition, there are many competitors in the industry producing functional product such as food and beverages . In other side, from Disperindagkop Sleman Regency point of view, the skill to make innovative product such as handy craft is more preferable. It is because Mount Merapi is one of tourism destination, so if the survivors is able to make handy craft product or any other innovative product it will give them opportunity to generate unique products. As the tourism destination, the unique products can be a souvenir for the trourist. In the 
long term, according to Disperindagkop Sleman Regency it will generate more profict to the survivors. Our suggestion for disaster recovery program is that at the beginning, it is better to provide the survivor with the skill that enable them to make functional product. Once this program is successfully implemented by the survivors, then another disaster recovery program that enable the survivor to produce innovative product can be delivered to the survivor.

\section{REFERENCES}

Chang, Y., Wilkinson, S., Potangaroa, R., Seville, E. (2012). Resourcing for post-disaster reconstruction: a comparative study of Indonesia and China. Disaster Prevention and Management, 21, 7-21.

Cox, R.S. \& Perry, K.M.E. (2011). Like a Fish Out of Water: Reconsidering Disaster Recovery and the Role of Place and Social Capital in Community Disaster Resilience. American Journal of Community Psychology, 48, 395-411.

Kusumasari, B. \& Alam, Q. (2012a). Bridging the gaps: the role of local government capability and the management of a natural disaster in Bantul, Indonesia. Natural Hazards, 60, 761-779.

Kusumasari, B. \& Alam, Q. (2012b). Local wisdom-based disaster recovery model in Indonesia. Disaster Prevention and Management, 2, 351-369.

Thurairajah, N. \& Baldry, D. (2010). Women's Empowerment in Post Disaster Reconstruction: Perspectives on Policies and Frameworks. International Journal of Strategic Property Management, 14, 347-361.

www.bnpb.go.id-retrieved 2011)we can send this reference to the end, reference part. 